\title{
TAXONOMIC STUDIES ON GENUS SPILARCTIA BUTLER (ARCTIINAE: ARCTIIDAE: LEPIDOPTERA) FROM INDIA
}

\author{
Amritpal Singh Kaleka
}

Department of Zoology, Punjabi University, Patiala, Punjab 147002, India

Email: amritpalkaleka@ indiatimes.com

\section{Abstract}

The morphological characters of the external genitalia of eight Indian species of genus Spilarctia Butler have been studied and illustrated. The paper gives the distribution of these species. A key to the Indian species of this genus is also given.

KEYWORDS

Arctiidae, genitalia, key, Lepidoptera, Spilarctia, taxonomy

AbBreviations

ACC.SC - Accesory sac; AED - Aedeagus; ANT.APO - Anterior apophyses; CO - Costa; CRN - Cornuti; CRP.BU - Corpus bursae; DU.BU - Ductus bursae; DU.EJ. - Ductus ejaculatoris; JX - Juxta; PAP.A - Papilla analis; PO.APO - Posterior apophyses; SA Saccus; SL - Sacculus; TG - Tegumen; TRA - Transtilla; UN Uncus; VES - Vesica; VIN - Vinculum; VLV - Valvula

The genus Spilarctia Butler was erected on the type species Phalaena lutea Hufnagel. Hampson (1894) synonymised the genus Spilarctia under genus Spilosoma Stephens and later on placed both these genera under Diacrisia Hübner (Hampson, 1901). Seitz (1910) while introducing the division of Arctiinae into Spilosominae, Micrarctiinae and Arctiinae, separated some of the old world species placed in the genus Diacrisia Hübner (Hampson, 1901) into Spilarctia, and treated Diacrisia under subfamily Arctiinae. Watson et al. (1980) listed all these three genera i.e., Spilarctia, Spilosoma and Diacrisia as valid generic names with lutea Hufnagel, menthastri Denis \& Shiffermuller and russulla Linnaeus as their type species. Koda (1988) studied the male and female genitalic structures of these type species. In the present study sixty six individuals of tiger moths belonging to eight species viz., erthrozona (Kollar), leopardina (Kollar), casigneta (Kollar), irregularis (Rothschild), rubilinea (Moore), comma (Walker), niceta (Stoll) and obliqua (Walker) under genus Spilarctia Butler (Hampson, 1894, 1901; Arora \& Chaudhury, 1982; Holloway, 1988; Koda, 1987, 1988; Fang 2000) were collected from different localities of Assam, Himachal Pradesh, Jammu \& Kashmir, Nagaland Punjab, Sikkim, Uttaranchal and West Bengal. These species were identified on the basis of taxonomically important features such as labial palpi, wing venation and maculation and comparisons with the identified collections of the National Museums. Besides this, the male and female genitalic characters have also been studied and illustrated in detail. The terminology by Klots (1970) has been followed for naming different parts of the genitalia. The critical examination of these taxonomic features revealed that all these species completely conform to the characterization of the type species of genus spilarctia and are congeneric. In addition to the above five more species of genus Spilarctia was also studied from the multiguttata complex (Kaleka, 2005). A key to the
Indian species of this genus is given.

\section{Spilarctia Butler, 1875}

Butler, 1875, Cistula Ent. 2: 39; Straudinger, 1891, Dt. Ent. Z. Iris. 4: 161-162; Moore, 1882, Lepid. Ceylon 3: 71; Seitz, 1910, Macrolep. World 2: 84; Koda, 1988, Tyo to Ga 39(1): 58-67.

\section{Spilarctia erthrozona (Kollar) \\ (Figs. 1-4)}

Euprepia erthrozona Kollar, 1844, In Hugel's Kaschmir und das Reich der Siek, 4: 468; Hampson, 1894, Moths Ind. 2: 11; id., 1901, Cat. Lep. Phal. 3: 265; Kirby, 1892, Cat. Het. 1: 232. Spilosoma cognata Walker, 1869, Char. Undescribed Het. 1869: 11; Kirby, 1892, Cat. Het. 1: 234. Material examined: 2 males, 16.vi.1993, Bharmour, Himachal Pradesh, 2195m. 1 male, 28.viii.1994, Patnitop, Jammu \& Kashmir, $2100 m$. Type locality: Kashmir

Male genitalia: Uncus of moderate size, broad, triangular, tip blunt and curved, dorsally setosed; acrotergite large; fenestrula absent; tegumen of moderate size, slightly longer than vinculum; vinculum Ushaped; saccus reduced. Valva short and broad; saccular margin with a distinct finger like projection; distal end hammer-shaped; juxta well developed, trapezoid, apical margin emarginated; transtilla prominent. Aedeagus with anterior tip rounded, both of its walls equally sclerotized; distal half with a sclerotized shield like structure, beset

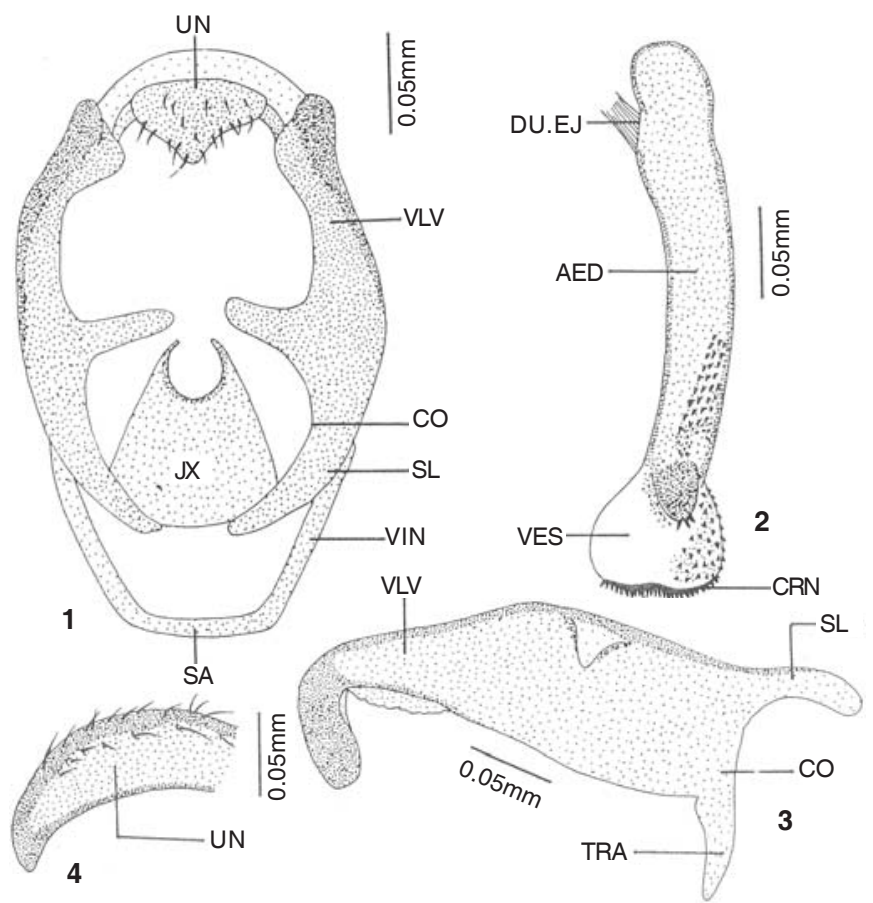

Figures 1-4. Male genitalia of Spilarctia erthrozona (Kollar)

Manuscript 1685; (C) ZOO; Date of publication 21 August 2007 Received 30 November 2006; Revised received 03 May 2007; Finally accepted 10 August 2007 
with spines; vesica armed with large number of densely packed spines at distal end and denticles.

Wing expanse (half): Male: 19mm; Female: Not examined Distribution: India: North West Himalayas; Elsewhere: China.

\section{Spilarctia leopardina (Kollar)}

(Figs. 5-9)

Euprepia leopardina Kollar, 1844, In Hugel's Kaschmir und das Reich der Siek, 4: 467; Hampson, 1894, Moths Ind. 2: 22; id., 1901, Cat. Lep. Phal. 3: 288; Kirby, 1892, Cat. Het. 1: 240. Arctia divisa Walker, 1855, Cat. Lep. Het. 3: 614; Butler, 1881, Illust. Het. B. M. 5: 33. Ardices liturata Walker, 1869, Char. Lep. Het. 1869: 12; Kirby, 1892, Cat. Het. 1: 239.

Material examined: 1 male, 30.vi.1994, Nanital, Uttaranchal, 1938m; 1 female, 10.vi.1995, Loharkhet, 1753m.

Type locality: North West Himalayas.

Male genitalia: Uncus of moderate size, curved ventrally, setosed, tip blunt; acrotergite well developed; fenestrula absent; tegumen almost double length of vinculum; vinculum U-shaped; saccus reduced. Valva simple; sacculus and costa not well defined; saccular margin with a projection near distal end; distal end bifurcated with unequal projections and setosed; juxta large, trapezoid, apical margin emarginated; transtilla prominent. Aedeagus short, anterior tip rounded, semi-sclerotized; vesica armed with two patches of prominent spines and a large number of fine denticles.

Female genitalia: Corpus bursae globular, anterior portion membranous, posterior portion well sclerotized, bearing sclerotized lines; ductus bursae of moderate size, well sclerotized; anterior apophyses less than half length of posterior ones, both pairs with their apices narrow; papilla analis triangular and broad, fringed with fine micro and macro setae.

Wing expanse (half): Male: $22 \mathrm{~mm}$; Female: $28 \mathrm{~mm}$

Distribution: India: North West Himalayas; Elsewhere: China.

\section{Spilarctia casigneta (Kollar)}

Euprepia casigneta Kollar, 1844, In Hugel's Kaschmir und das Reich der Siek, 4(2): 469; Hampson, 1894, Moths Ind. 2: 9; id., 1901, Cat.
Lep. Phal. 3: 281; Kirby, 1892, Cat. Het. 1: 231.

Material examined: 1 female, 8.ix.1995, Dharamshala, Himachal Pradesh, 1200m; 1 male, 16.vii.1991, Shimla, 2205m. 1 male, 7.v.1995, 3 males, 8.v.1995, 1 female, 14.v.1995, Mangan, Sikkim, 1200m.

Type locality: Kashmir.

Male genitalia: Uncus short, broad, triangular, tip blunt, dorsally setosed, with a central slight hood like structure at tip; large acrotergite present; fenestrula absent; tegumen with outer wall straight, inner wall convex, longer than vinculum; vinculum U-shaped, well sclerotized; saccus reduced. Valva simple, moderately long and narrow, sacculus and costa well defined; sacculus with a distinct projection above middle of valva; cucullus and valvula fused to form a distal hammer-shaped projection; juxta large, clypeiform, emarginated at apex, having bifid appearance; transtilla long, sclerotized and bar like. Aedeagus long, tip rounded, both of its walls equally sclerotized; a distinct sclerotized shield attached on distal end of aedeagus, bearing many small and three prominent spines, vesica armed with congregations of small denticles and spines below middle and at distal end.

Female genitalia: Corpus bursae rounded, membranous, signum absent; ductus bursae long, anterior half narrow and membranous, posterior half broad, coiled and highly sclerotized; anterior apophyses short, broad at base, apices pointed, posterior ones long, with their apices blunt; papilla analis triangular and rounded, clothed with many small and few large setae. (Illustrated by Kirti \& Singh 1994.)

Wing expanse (half): Male: $20-22 \mathrm{~mm}$; Female: $21-25 \mathrm{~mm}$

Distribution: India: North West Himalayas, Sikkim; Elsewhere: China.

\section{Spilarctia irregularis (Rothschild)}

(Figs. 10-13)

Diacrisia irregularis Rothschild, 1910, Novit Zool. 17: 125; Hampson, 1920, Cat. Phal. Br. Mus. Suppl. 2:369.

Material examined: 2 males, 13.ix.1995, Lachen, Sikkim, 3300m. 1 male, 28.iv.1995, Kurseong, West Bengal, 2200m.

Type locality: China.

Male genitalia: Uncus triangular, broad at base, curved ventrally towards distal end, tip blunt, dorsally setosed; acrotergite well developed; fenestrula absent; tegumen well sclerotized, almost double length of vinculum; vinculum U-shaped; saccus reduced. Valva

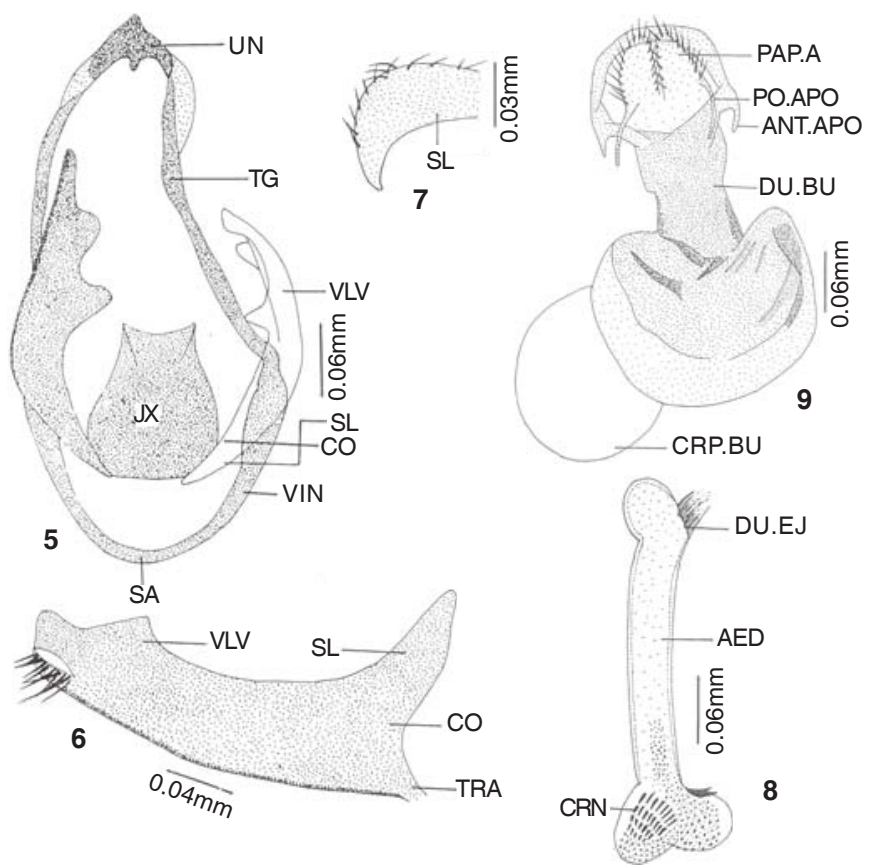

Figures 5-9. Spilarctia leopardina (Kollar) 5-8 - Male genitalia; 9 - Female genitalia

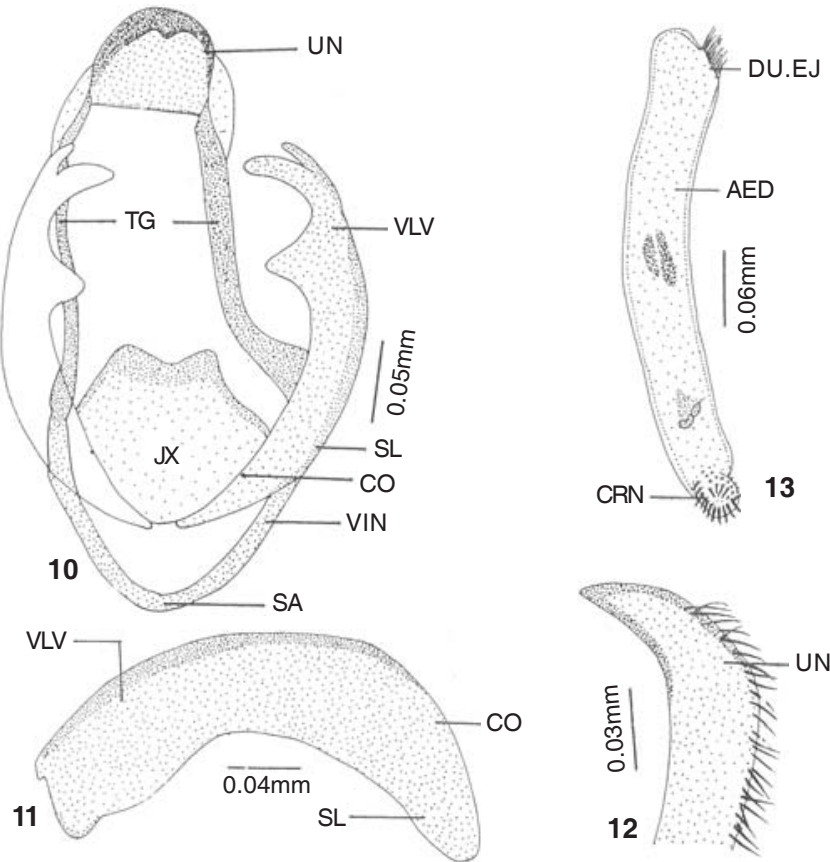

Figures 10-13. Male genitalia of Spilarctia irregularis (Rothschild) 
simple; sacculus distinct; costa narrow, triangular projection near distal end; distal end bifid; juxta trapezoid, apical margin emarginated; transtilla not defined. Aedeagus long, semi-sclerotized, with two small patches in middle; vesica armed with prominent spines and denticles.

Wing expanse (half): Male: $22 \mathrm{~mm}$; Female: Not examined Distribution: India: Sikkim, Meghalaya, West Bengal; Elsewhere: China, Myanmar.

\section{Spilarctia rubilinea (Moore) \\ (Figs. 14-18)}

Spilosoma rubilinea Moore, 1865, Proc. Zool. Soc., 1865: 810; Hampson, 1894, Moths Ind. 2: 8; Kirby, 1892, Cat. Het. 1: 231. Spilosoma discinigra Moore, 1865, Proc. Zool. Soc., 1865: 810; Kirby, 1892, Cat. Het. 1: 232.

Material examined: 1 male, 07.vii.1991, Solan, Himachal Pradesh, 1340m. 1 female, 16.ix.1994, Zunheboto, Nagaland, 1570m. 3 males, 13.v.1995, Lachen, Sikkim, 2970m; 1 male, 07.v.1995, Mangan, 1200m. 1 female, 20.ix.1995, Kempty falls, Uttaranchal, 1524m. 1 male, 01.v.1995, Jorebunglow, West Bengal, 1759m.

Type locality: Sikkim.

Male genitalia: Uncus of moderate size, swollen at base, lateral walls slightly produced outwards, curved ventrally, setosed with fine setae on dorsal side, tip blunt; acrotergite covering lower half of uncus; fenestrula absent; tegumen well developed, slightly shorter than vinculum; vinculum U-shaped; saccus reduced. Valva simple and narrow; sacculus distinct; costa narrow; saccular margin produced at distal end; bifid at tip and setosed; juxta distinct, saucer shaped, apical margin emarginated; transtilla prominent. Aedeagus moderately long, anterior tip rounded, slightly curved at distal end; vesica armed with a patch of a number of denticles.

Female genitalia: Corpus bursae rounded, membranous; signum wanting; ductus bursae highly sclerotized; accessory sac present; anterior apophyses slightly less than half length of posterior ones, apices rounded; papilla analis broad and rounded, fringed with micro and macro setae.

Wing expanse (half): Male: $21-25 \mathrm{~mm}$; Female: $24-28 \mathrm{~mm}$

Distribution: India: Assam, Himachal Pradesh, Sikkim, Meghalaya, Uttaranchal, West Bengal; Elsewhere: China and Myanmar.

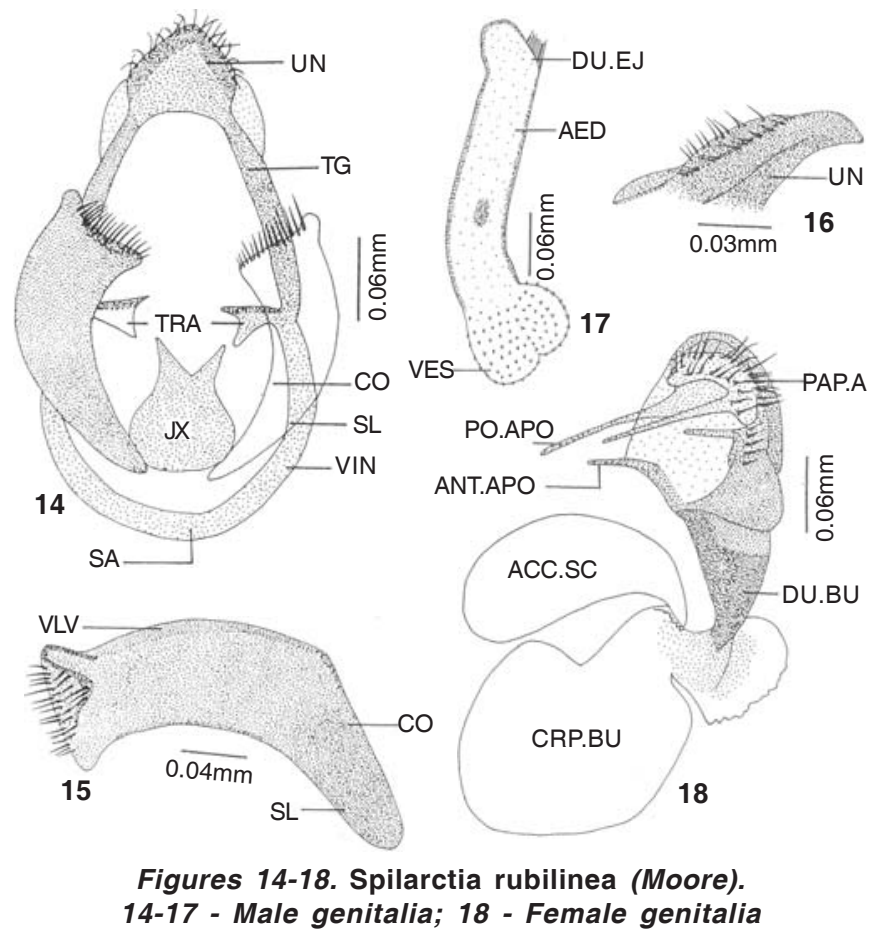

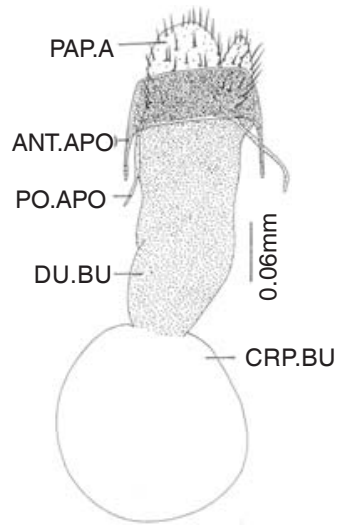

Figure 19 - Female genitalia of Spilarctia comma (Walker)

\section{Spilarctia comma (Walker) \\ (Fig. 19)}

Aloa comma Walker, 1856, Specimens Lepid. Insects Colln Br. Mus. 7: 1703; Hampson, 1894, Moths Ind. 2: 10; id., 1901, Cat. Lep. Phal. 3: 285; Kirby, 1892, Cat. Het. 1: 242. Spilosoma abdominalis Moore, 1859, Lep. E.I.C. 1859: 356; Butler, 1881, Illust. Het. B. M. 5: 31; Kirby, 1892, Cat. Het. 1: 231.

Material examined: 1 male, 06.06.1994, Manali, Himachal Pradesh, 2050m. 1 male, 15.vi.1994, Chakrata, Uttaranchal, 2100m; 1 female, 13.x.1991, Mussorrie, 2030m; 1 female, 02.vii.1994, Ranikhet,1830m. Type locality: N.W. Himalayas.

Male genitalia: illustrated by Kirti and Singh 1994.

Female genitalia: Corpus bursae circular, membranous; ductus bursae long, well sclerotized; anterior apophyses less than half length of posterior ones, anterior apophyses with apices narrow; papilla analis broad and rounded, fringed with fine setae.

Wing expanse (half): Male: $23-25 \mathrm{~mm}$; Female: $25 \mathrm{~mm}$.

Distribution: India: N. W. Himalayas; Elsewhere: China, Myanmar.

\section{Spilarctia niceta (Stoll)}

(Figs. 20-24)

Bombyx niceta Stoll, 1782, Pap. Exot. 4: 368; Hampson, 1901, Cat. Lep. Phal. 3: 317; Kirby, 1892, Cat. Het. 1: 912.

Material examined: 1 female, 10.ix.1991; 1 male, 27.ix.1995; 1, female, 29.ix.1995; 1 male, 01.x.1995, Jatinga, North Cachar hills, Assam, 900m.

Type locality: China

Male genitalia: Uncus of moderate length, broad in middle, tip blunt, curved towards distal end; acrotergite covering lower half of uncus; fenestrula absent; tegumen well developed, long, almost double length of vinculum; vinculum broad, U-shaped; saccus reduced. Valva simple, long; sacculus distinct; costa narrow; a knob-like projection near distal end; distal end hammer shaped; juxta large, trapezoid, apical margin emarginated; transtilla well developed. Aedeagus long, anterior tip broad, both of its walls equally sclerotized; a sclerotized plate with denticulate margin present at distal end; vesica armed with prominent spines and a large number of denticles.

Female genitalia: Corpus bursae globular, membranous; signum missing; ductus bursae as broad as long, highly sclerotized; anterior apophyses half length of posterior ones, both pairs with their apices rounded; papilla analis broad, setosed with fine micro setae.

Wing expanse (half): Male: $21 \mathrm{~mm}$; Female: $\quad 26 \mathrm{~mm}$

Distribution: India: Assam; Elsewhere: China, Philippines, Ireland.

Remarks: Reporting of this species from Jatinga is its first record from India.

\section{Spilarctia obliqua (Walker)}

Walker, 1854, Specimens Lepid. Insects Colln Br. Mus. 3: 678; Hampson, 1894, Moths Ind. 2: 10; id., 1901, Cat. Lep. Phal. 3: 285; 


\section{Key to the species of genus Spilarctia Butler}

1. Forewing with limited black spots; abdomen decorated with crimson scales; valva of male genitalia with gradually

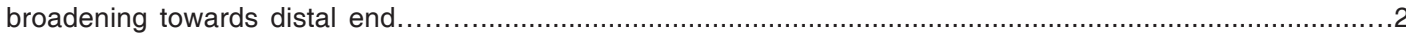
Forewing with numerous series of black spots; abdomen decorated with yellow scales; valva of male genitalia

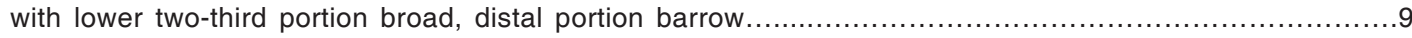

2. Labial palpus clothed with black scales on sides and underside ...................................................... Labial palpus streaked with crimson scales on sides, underside fringed with yellow scales..........................

3. Wings with ground colour white, no antemedial and postmedial spots; legs dressed with white scales; abdomen with dorsal segmental black bands and lateral series of black spots.......................................erthrozona (Kollar) Wings with ground colour yellowish brown or yellowish white, with antemedial and postmedial spots or fascia; legs dressed with black scales; abdomen with dorsal, lateral and sublateral series of black spots..........................4

4. Thorax and collar with broad black fascia; tegula dressed with black scales; forewing with broad black fascia covering up to median nervure, another fascia along inner margin; hind wing with black patches; legs with tibia and tarsi streaked with yellow scales; valva of male genitalia having apical portion bifurcated with unequal projections, setosed. leopardina (Kollar) Thorax and collar without fascia; tegula dressed with yellowish brown scales; forewing with antemedial, postmedial and submarginal black spots; hind wing without black patches; legs with tibia and tarsi not streaked with yellow scales; valva of male genitalia without bifurcation in apical part...

5. $\quad$ Forewing with veins R2-R5 stalked from before upper angle of cell, obscure scarlet or crimson lines or bands present; aedeagus without any sclerotized shield at distal end.......................................................... Forewing with veins R2-R5 stalked from upper angle of cell, without any lines or bands present; aedeagus with a sclerotized shield at distal end casignata (Kollar)

6. Legs dressed with black scales; male genitalia with valva having a distinct saccular projection; juxta trapezoid; aedeagus long, vesica armed with prominent spines and denticles...............................irregularis (Rothschild) Legs with forecoxa streaked with crimson scales on sides, femur dressed with crimso7un scales on upperside, fringed with yellow scales on under side; male genitalia with valva having no saccular projection; juxta saucer shaped; aedeagus of moderate size, vesica armed with a patch of sclerotization and number ofdenticles.

rubilinea (Moore)

7. Forewing with ground colour carneose, having an antemedial and a postmedial black spot on costa; male genitalia with valva having wide costa; vinculum with both of its walls produced outwardly; a setosed saccular projection; juxta shield like comma (Walker)

- $\quad$ Forewing with ground colour orange or pale yellow, no spots on costa; male genitalia with valva having narrow costa; vinculum with both of its walls not produced outwardly; saccular projection missing; juxta trapezoid..........8

8. Forewing with postmedial spots on either side of veins Cu2 \& $1 \mathrm{~A}$; male genitalia with tegumen almost double the length of vinculum; valva with distal end bifurcated; aedeagus with a sclerotized shield having denticulate margins. niceta (Stoll) Forewing with postmedial spots on either side of veins $\mathrm{M} 2$ to $1 \mathrm{~A}$; male genitalia with tegument almost same size of vinculum; valva with distal end not bifurcated; aedeagus without any sclerotized shield..... ..obliqua (Walker)

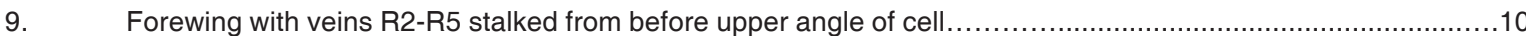

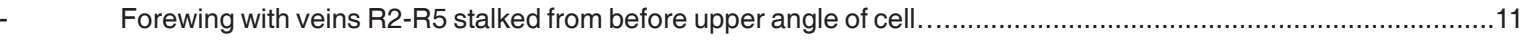

10. Collar and tegula clothed with white scales; forewing with four sub basal black spots and medial series of seven spots; male genitalia with acrotergite covering lower half of uncus; valva with a triangular projection near distal end; aedeagus long with two congregations of small spines and denticles and four large spines at distal end... ...multiguttata (Walker) Collar and tegula clothed with pale yellow scales; forewing with three subbasal black spots and medial series of six spots; male genitalia with acrotergite covering almost three-fourths of lower portion of uncus; valva without any projection near distal end; aedeagus of moderate length, with numerous spines at distal end.

multicornutiata Kaleka

11. Tegula dressed with white scales; male genitalia with valva symmetrical, saccular margin rounded, a distinct projection near distal end; vinculum without flap like expansion .......................................................... 12 Tegula dressed with pale yellow scales; male genitalia with asymmetrical valva, saccular margin with rounded projection in left valva and bilobed in right valva; vinculum with flap like expansions .................nirmalae Kaleka

12. Hindwing with veins Rs and M1 originating from upper angle of cell, Cu1 from lower angle of cell; male genitalia with valva having distal end bifid; vinculum without lateral expansions; aedeagus short, vesica armed with fifteen distinct spines; female genitalia with corpus bursae rather large; anterior apophyses with blunt apices, posterior apophyses with pointed tips....................................................................himachalensis Kaleka Hindwing with veins Rs and M1 shortly stalked from upper angle of cell, Cu1 from before lower angle of cell; male genitalia with valva having distal end hammer shaped; vinculum with lateral expansions; aedeagus of moderate size, curved at distal end, vesica armed with numerous spines; female genitalia with corpus bursae small; both pair of apophyses with their apices rounded. ..valvata Kaleka 


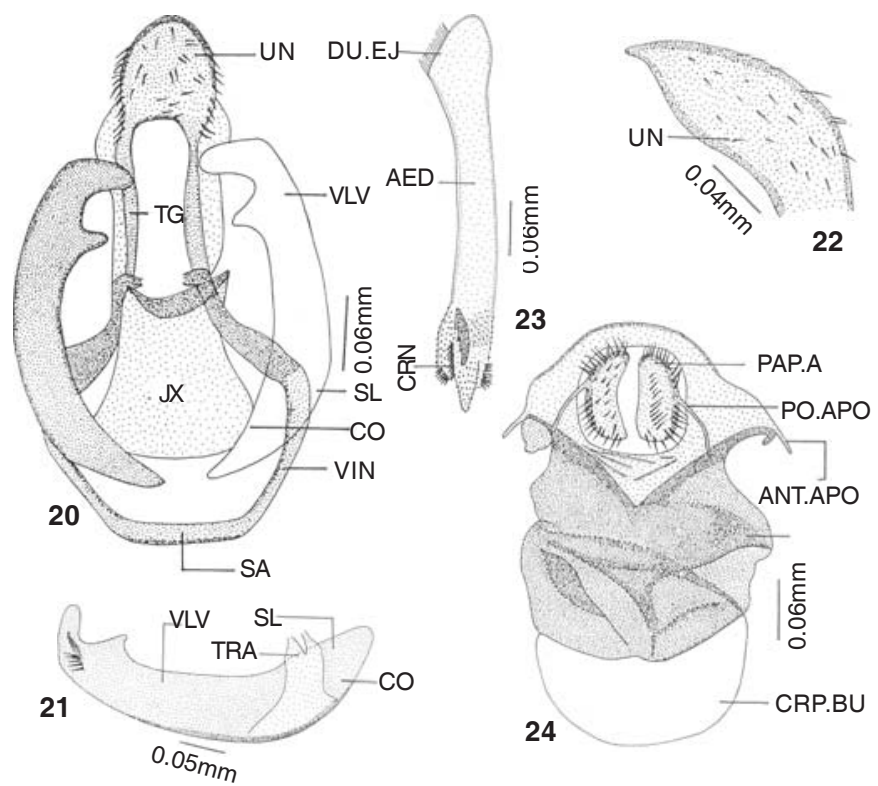

Figures 20-24. Spilarctia niceta (Stoll)

20-23 Male genitalia; 24 - Female genitalia

Kirby, 1892, Cat. Het. 1: 242. Moore, 1882, Lep. Cey. 2: 107.

Material examined: 1 male, 28.vi.1994, Narkanda, Himachal Pradesh; 8 males, 1 female, 27.viii.1994, Udhampur, Jammu \& Kashmir; 1 female, 20.ix.1991; males, 22.ix.1991, Patiala, Punjab; 5 females, 20.ix.1995, Kempty falls, Uttranchal; 2 females, 18.ix.1995; 3 females, 19.ix.1995; 5 females, 21.ix.1995; 3 females, 22.ix.1995; 1 female, 23.ix.1995, Mussorrie.

Type locality: India.

Male genitalia: Uncus of moderate size, tip blunt, dorsally setosed, curved ventrally; large acrotergite present; fenestrula absent; tegumen inverted U-shaped, well sclerotized; vinculum slightly shorter than tegumen; saccus small. Valva simple, sacculus slightly defined, costa ill defined; cucullus and valvula fused, tip broad and setosed; juxta saucer shaped; transtilla well developed and triangular. Aedeagus long, slightly constricted at middle; vesica furnished with four prominent and number of denticles representing cornuti.

Female genitalia: Corpus bursae small, membranous, lower portion sclerotized signum absent; ductus bursae broadening towards ostium bursae well sclerotized; anterior apophyses shorter than posterior ones long, with their apices rounded; papilla analis large and triangular, fringed with macro and micro setae. (Illustrated by Kirti \& Singh 1994.) Wing expanse (half): Male: 20-22mm; Female: 21-25mm

Distribution: India: Throughout; Elsewhere: China.

\section{REFERENCES}

Arora, G.S. \& M. Chaudhury (1982). On the lepidopterous fauna of Arunachal Pradesh and adjoining areas of Assam in north east India: Family: Arctiidae. Zoological Survey of India- Technical Monograph 6: 166 .

Fang, C. (2000). Fauna Sinica. Insecta. Chinese Academy of Sciences, Beijing, China, 19: 1-89 $+\mathrm{xx}$ plates.

Hampson, G.F. (1894). Fauna of British India, Moths, including Ceylon and Burma 2. Taylor and Francis Ltd., London, 609pp.

Hampson, G.F. (1901). Catalogue of the Lepidoptera Phalanae in the British Museum Collection, 3: 1-690.

Holloway, J.D. (1988). Moths of Borneo, Arctiidae (Syntominae, Euchromiinae, Arctiinae), Aganainae (to Noctuidae) 6: 1-101, Kuala Lumpur. Kaleka, A.P.S. (2005). The multiguttata complex of the genus Spilarctia Butler (Arctiinae: Arctiidae: Lepidoptera) from India. Entomon 30(3): 207-220.
Kirti, J.S. \& A.P.S. Kaleka (1994). Genitalic studies on four Indian species of genus Spilarctia Butler (Arctiidae: Lepidoptera). Uttar Pradesh Journal of Zoology 14(1): 87-88.

Klots, A.B. (1970). Lepidoptera, pp.115-130. In: S.L. Tuxen (ed.). Taxonomist's Glossary of Genitalia in Insects. Munksgaard, Copenhagen.

Koda, N. (1987). A generic classification of the subfamily Arctiinae of Palaearctic \& oriental regions based on male \& female genitalia (Lepidoptera: Arctiidae) Part-1. Tyo to ga 39(1): 153-237.

Koda, N. (1988). A generic classification of the subfamily Arctiinae of Palaearctic \& oriental regions based on male \& female genitalia (Lepidoptera: Arctiidae) Part-1. Tyo to ga 38(3): 1-79.

Robinson, G.S. (1976). The preparations of studies of Lepidoptera genitalia with special reference to Microlepidoptera. Entomologie Gazette 27(2): 127-132.

Watson, A., D.S. Fletcher \& I.W.D. Nye (1980). The Generic Names of The Moths of World 2. Noctuoidea, 228pp.

\section{ACKNOWLEDGEMENTS}

The author is thankful to CSIR, New Delhi for financial assistance.

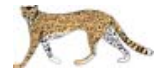

\section{Required}

Two field researchers for a year long study on "Seed dispersal and regeneration of hornbill dispersed tree species in the Eastern Himalayas." This research is a continuation of an ongoing study in Pakke Tiger Reserve and adjoining Reserve Forests. The focus of the research is on the consequences of anthropogenic disturbance (primarily hunting and logging) on hornbill densities and the recruitment of their food plants and encompasses bird surveys (of hornbills and other frugivorous species), focal tree watches and vegetation assessments.

The project will be initiated in August/September 2007 (time frame negotiable) and will continue for a period of one year with the possibility of a six month extension. A monthly stipend equivalent to JRF/SRF scales of UGC as found applicable will be paid for the duration of the study. In addition, field costs will be covered.

Candidates should possess a Master's degree in Wildlife biology/Ecology/Zoology or a related field of biology and be willing to work in extremely demanding field conditions. Prior field experience in bird identification (particularly Himalayan species) and field techniques is highly desirable.

If interested please contact

Pia Sethi, Doctoral candidate,

Department of Biological Sciences,

University of Illinois at Chicago,

845 W. Taylor Street (M/C 066),

Chicago, IL-60607

Email: psethi@uic.edu; sethipia@yahoo.com 